\title{
Correction to: Functional analysis of suspected splicing variants in CLCN5 gene in Dent disease 1
}

\author{
Tomohiko Inoue ${ }^{1,2}$. China Nagano ${ }^{1}$ (D) Masafumi Matsuo ${ }^{3} \cdot$ Tomohiko Yamamura $^{1}$ - Nana Sakakibara ${ }^{1}$ \\ Tomoko Horinouchi ${ }^{1}$ - Yugo Shibagaki ${ }^{2}$. Daisuke Ichikawa ${ }^{2}$ - Yuya Aoto ${ }^{1}$ - Shinya Ishiko ${ }^{1}$. Shingo Ishimori ${ }^{1}$. \\ Rini Rossanti ${ }^{1} \cdot$ Kazumoto lijima ${ }^{1} \cdot$ Kandai Nozu $^{1}$
}

Published online: 15 March 2021

(c) The Author(s) 2021

\section{Correction to: Clinical and Experimental Nephrology (2020) 24:606-612 https://doi.org/10.1007/s10157-020-01876-x}

The article "Functional analysis of suspected splicing variants in CLCN5 gene in Dent disease 1", written by Tomohiko Inoue $\cdot$ China Nagano $\cdot$ Masafumi Matsuo $\cdot$ Tomohiko Yamamura · Nana Sakakibara ·Tomoko Horinouchi · Yugo Shibagaki · Daisuke Ichikawa · Yuya Aoto · Shinya Ishiko - Shingo Ishimori ·Rini Rossanti · Kazumoto Iijima and Kandai Nozu was originally published Online First without Open Access. After publication in volume 24, issue 7, page 606-612 the author decided to opt for Open Choice and to make the article an Open Access publication. Therefore, the copyright of the article has been changed to (C) The Author(s) 2021 and the article is forthwith distributed under the terms of the Creative Commons Attribution 4.0 International License (https://creativecommons.org/licenses/ by/4.0/), which permits use, sharing, adaptation, distribution and reproduction in any medium or format, as long as you give appropriate credit to the original author(s) and the source, provide a link to the Creative Commons licence,

The original article can be found online at https://doi.org/10.1007/ s10157-020-01876-x

\section{China Nagano}

china@med.kobe-u.ac.jp

1 Department of Pediatrics, Kobe University Graduate School of Medicine, 7-5-1 Kusunoki-cho, Chuo-ku, Kobe, Hyogo 650-0017, Japan

2 Division of Nephrology and Hypertension, St. Marianna University Graduate School of Medicine, 2-16-1 Sugao, Kawasaki City, Kanagawa 216-8511, Japan

3 Department of Physical Therapy, Faculty of Rehabilitation, Kobe Gakuin University, 518 Arise, Ikawadani-cho, Nishi-ku, Kobe, Hyogo 651-2180, Japan and indicate if changes were made. The original article has been corrected.

Open Access This article is licensed under a Creative Commons Attribution 4.0 International License, which permits use, sharing, adaptation, distribution and reproduction in any medium or format, as long as you give appropriate credit to the original author(s) and the source, provide a link to the Creative Commons licence, and indicate if changes were made. The images or other third party material in this article are included in the article's Creative Commons licence, unless indicated otherwise in a credit line to the material. If material is not included in the article's Creative Commons licence and your intended use is not permitted by statutory regulation or exceeds the permitted use, you will need to obtain permission directly from the copyright holder. To view a copy of this licence, visit http://creativecommons.org/licenses/by/4.0/.

Publisher's Note Springer Nature remains neutral with regard to jurisdictional claims in published maps and institutional affiliations. 